RADOSŁAW ULISZAK

Uniwersytet Pedagogiczny w Krakowie

\title{
Przejawy kryzysu we współczesnym rolnictwie
}

Z przeglądu literatury przedmiotowej, artykułów prasowych, a także z codziennych doniesień agencji informacyjnych wynika, że kryzys dotyczący rolnictwa widoczny jest w wielu postaciach. Mówi się między innymi o kryzysie ekologicznym w odniesieniu do rolnictwa uprzemysłowionego, wymienia się kryzysy związane z błędną polityką rolną (lub jej brakiem), jak również łączy się go często z niedoborem żywności widocznym w różnych regionach świata oraz z rynkami rolnymi. Wskazywana bywa również zależność rolnictwa od procesów kryzysowych zachodzących w gospodarce światowej.

Kryzysy rolnicze wydają się mieć jednak inny charakter niż kryzysy ogólnogospodarcze. Rolnictwo dostarcza żywności, która jest produktem pierwszej potrzeby - niezbędnym do życia. Na podaż i popyt wielu dóbr i usług znaczny wpływ mają takie czynniki jak moda, presja społeczna czy koniunktura. Zapotrzebowanie na podstawową żywność wynika z bardziej fundamentalnych potrzeb.

W poniższym opracowaniu scharakteryzowano najważniejsze przejawy współczesnego kryzysu występującego w rolnictwie, które wynikają nie tylko z ogólnie trudnej sytuacji ekonomicznej czy politycznej współczesnego świata, ale są także następstwem takich zjawisk przyrodniczych, jak susze, ulewy, powodzie czy gradobicia.

W niniejszej pracy wychodzę z założenia, że kryzysy w rolnictwie charakteryzują takie zmiany społeczno-ekonomiczne, jak spadek produkcji rolniczej, spadek dochodów ludności rolniczej, bezrobocie w rolnictwie, depopulacja na obszarach rolniczych i występowanie dysparytetu dochodów ludności rolniczej w stosunku do innych grup pracowniczych. Istotne w podejściu do kwestii związanych z kryzysami rolniczymi jest też stwierdzenie, że ich skutki są obecnie łagodzone poprzez interwencyjne działania państw i rządów, które mają przede wszystkim zapobiegać dużym spadkom produkcji roślinnej czy zwierzęcej (np. zakupy interwencyjne, ustalanie cen minimalnych). Współczesne wprowadzenie wysokointensywnych sposobów uprawy roli doprowadziło w wielu regionach (zwłaszcza Europy) do negatywnych zmian w środowisku przyrodniczym zwanych kryzysem ekologicznym.

Kryzysy w rolnictwie rzadko mają wymiar ogólnoświatowy, a najczęściej są widoczne $\mathrm{w}$ niektórych regionach naszego globu obejmujących grupy państw lub nawet pojedyncze kraje czy ich regiony (np. niektóre części Indii).

Wśród najczęściej wyróżnianych rodzajów kryzysów dotyczących rolnictwa należy wymienić przede wszystkim: 
- wynikające z przyczyn przyrodniczych - braki i tzw. klęski urodzaju w produkcji rolniczej wywołane czynnikami naturalnymi (susze, powodzie, wyjątkowo sprzyjające stany pogody w danym roku, itp.);

- kryzys ekologiczny - rolnictwo próbując nadążyć z produkcją za przyrostem ludności lub w wyniku zwiększania zysków nadmiernie eksploatuje zasoby naturalne lub degraduje jakość środowiska poprzez nadużywanie środków chemicznych;

- wynikające ze wzrostu cen środków produkcji - zwiększenie kosztów produkcji w rolnictwie (paliwa, nawozy mineralne) i obniżenie dochodów rolniczych;

- wynikające z kryzysu politycznego - ograniczenia w funkcjonowaniu rolnictwa (spadek produkcji, trudności ze zbytem wytworzonych produktów, niedostateczna podaż artykułów rolniczych, duże braki w zaopatrzeniu mieszkańców w żywność) związane z kryzysami politycznymi (wojny, rozruchy polityczne, embargo na dostawy towarów, perturbacje w dostępie do rynków zbytu);

- wynikające z kryzysu ekonomicznego - ograniczenie siły nabywczej konsumentów, zwiększenie obciążenia rolnictwa bezrobotnymi, pogarszające się saldo handlu zagranicznego;

- wynikające z przyczyn demograficznych - pogłębiające się trudności społeczne rolnictwa związane z szybkim przyrostem ludności (eksplozja demograficzna), z dużym bezrobociem w rolnictwie, z postępującym się starzeniem ludności na obszarach rolniczych.

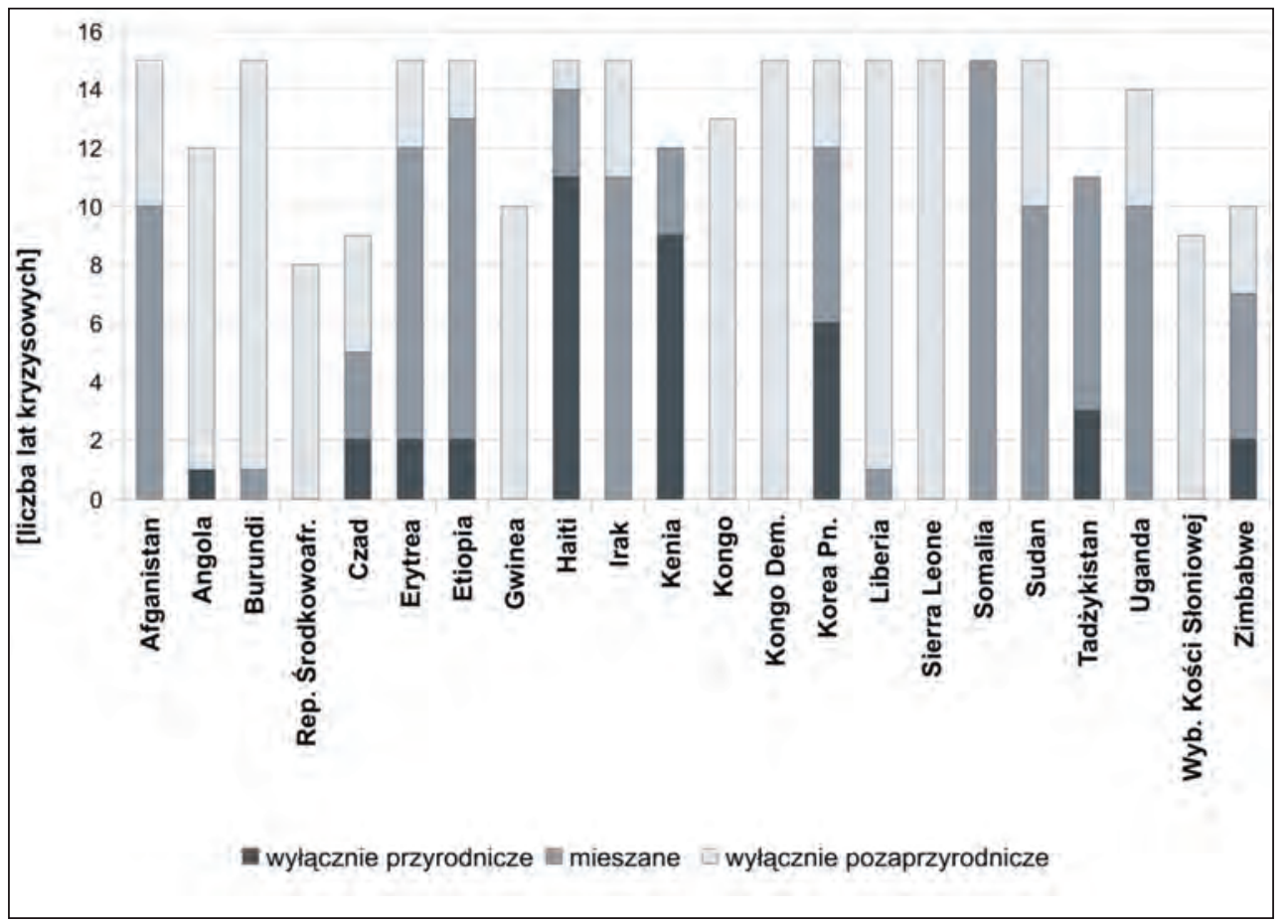

Ryc. 1. Liczba lat kryzysowych w okresie 1996-2010 w rolnictwie w krajach o niestabilnej gospodarce i sytuacji politycznej 
Według opracowań FAO (The State of Food...) dla większości krajów pozostających w ostatnich latach (1996-2010) w permanentnym kryzysie, źródłem problemów są przyczyny czysto przyrodnicze lub połączenie przyrodniczych z pozaprzyrodniczymi (ryc. 1). Na 22 kraje wymienione w tej analizie ponad połowa - bo 13 - zdominowana jest przez właśnie taki splot przyczyn powodujących ostry kryzys w rolnictwie.

W dalszej części pracy przedstawię najważniejsze przejawy kryzysów występujących w rolnictwie.

\section{KRYZYSY ROLNICZE ZWIĄZANE Z WARUNKAMI PRZYRODNICZYMI}

Rolnictwo wciąż pozostaje tym działem gospodarki, który jest niezwykle silnie związany z warunkami naturalnymi. Dzieje się tak pomimo bardzo dużego transferu osiagnięć nauki do rolnictwa i techniki rolnej. Środowisko jest najważniejszym elementem warunkującym przede wszystkim strukturę upraw roślinnych, a przebieg stanów pogody w danym roku bardzo często decyduje o poziomie zbiorów. $\mathrm{Z}$ tego też względu produkcja rolnicza podlega ogromnym wahaniom.

Najważniejszym produktem dostarczanym przez rolnictwo jest żywność, a w szczególności zboża. Susze, powodzie czy mrozy są więc czynnikami, które mogą mieć istotny i często negatywny wpływ na ich wzrost i plonowanie. Wahania poziomu zbiorów wynikające ze zmienności stanów pogody czy wręcz klęsk są pierwszym źródłem kryzysów związanych z rolnictwem. Kryzysów, które od zawsze były i przez wiele lat będą oczywistym zjawiskiem, bardzo często o charakterze ogólnoświatowym. Na światowy rynek żywności największy wpływ mają stany pogody (szczególnie występowanie opadów) w krajach dostarczających największą ilość ziaren zbóż na rynki wewnętrzne i na rynek światowy. Najważniejsi producenci od dawna to Chiny, Indie, Stany Zjednoczone, a ostatnio także Rosja. Ich produkcja to przeciętnie mniej więcej połowa zbiorów światowych. Dodatkowo są to kraje o licznej populacji, tak więc załamanie produkcji w którymś z nich natychmiast może skutkować ograniczeniami w ilości ziarna trafiającego na rynek światowy (wykarmienie własnych obywateli jest priorytetem). Wyjątkiem mogą być Stany Zjednoczone, które osiagają stale znaczne nadwyżki trafiające na eksport (ok. $80 \mathrm{mln}$ ton rocznie). Wśród eksportowanych przez ten kraj ziaren zbóż dominuje kukurydza, która ma zastosowanie zarówno paszowe jak i żywieniowe. Na kolejnych dwóch miejscach w amerykańskim eksporcie zbóż znajdują się jednak zboża typowo żywieniowe - pszenica i ryż (ryc. 2).

Obliczony na podstawie trendów w produkcji zbóż dla czterech przodujących krajów współczynnik zbieżności $\left(\varphi^{2}\right)$ pozwala stwierdzić, że najbardziej nieprzewidywalnym krajem pod względem zbiorów jest Rosja (por. tab. 1). Wymieniony współczynnik wynosi dla tego kraju aż 0,98 (podobnie np. Ukraina - 0,91) Świadczy to o bardzo dużych odstępstwach zbiorów w poszczególnych latach w stosunku do ogólnego trendu. Pośrednio wskazuje to na niewielką stabilność produkcji zbóż. Współczynnik ten dla Indii to tylko 0,21. Wartości te w kontekście podkreślanego zazwyczaj uzależnienia Indii od terminowości monsunu wydają się wskazywać, że kraj ten zapewne równoważy ewentualne straty w produkcji dwóch podstawowych zbóż, tj. pszenicy i ryżu (ryc. 4). W Rosji natomiast wpływ niekorzystnych warunków przyrodniczych jak i niestabilna sytuacja gospodarcza wydają się mieć duże znaczenie (ryc. 3). 


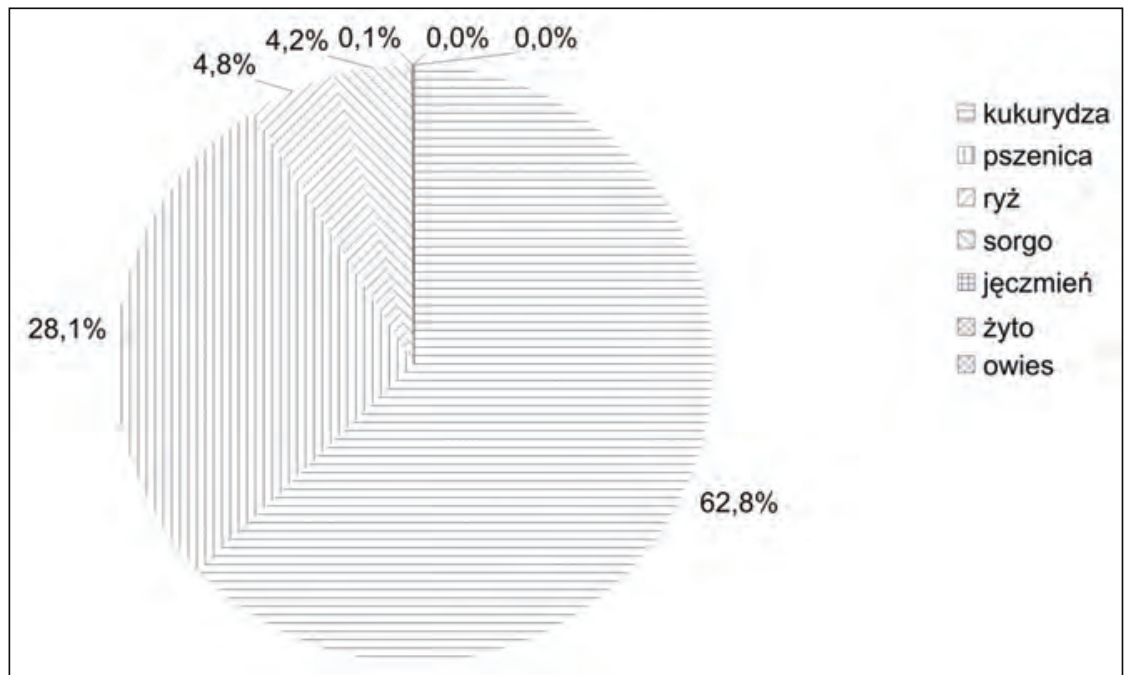

Ryc. 2. Struktura eksportu zbóż ze Stanów Zjednoczonych Ameryki w roku gospodarczym 2009/2010

Źródło: opracowanie własne na podstawie United States Department of Agriculture, Marketing Year Final Reports, http://www.fas.usda.gov/export-sales/myfi_rpt.htm 2010

Tab. 1. Najważniejsi producenci zbóż na świecie

\begin{tabular}{|l|c|c|c|c|c|}
\hline \multicolumn{1}{|c|}{ kraj } & $\begin{array}{c}\text { produkcja } \\
\text { zbóż w mln t } \\
{[1990]^{1}}\end{array}$ & $\begin{array}{c}\text { udział } \\
\text { w produkcji } \\
\text { światowej } \\
\text { w 1990 r. [\%] }\end{array}$ & $\begin{array}{c}\text { produkcja zbóż } \\
\text { w mln t [2009] }\end{array}$ & $\begin{array}{c}\text { udział } \\
\text { w produkcji } \\
\text { światowej } \\
\text { w 2009 r. [\%] }\end{array}$ & $\begin{array}{c}\text { współczynnik } \\
\text { zbieżności }\left(\varphi^{2}\right)\end{array}$ \\
\hline Chiny & 404,4 & 20,7 & 483,7 & 19,4 & 0,74 \\
\hline $\begin{array}{l}\text { Stany Zjedn. } \\
\text { Ameryki Płn. }\end{array}$ & 312,4 & 16,0 & 419,8 & 16,9 & 0,49 \\
\hline Indie & 193,9 & 9,9 & 246,8 & 9,9 & 0,21 \\
\hline Rosja & 103,8 & 5,3 & 95,1 & 3,8 & 0,98 \\
\hline
\end{tabular}

współczynnik zbieżności $\varphi^{2}$ obliczony w stosunku do trendu produkcji w latach 1990-2009 dla każdego z krajów;

${ }^{1}$ - w przypadku Rosji produkcja dla roku 1992 i okres 1992-2009 dla obliczenia współczynnika zbieżności

Źródło: opracowanie własne na podstawie http://faostat.fao.org (2010)

Mimo wahań w produkcji zbóż, które podano wcześniej, a które wywołują spore perturbacje na rynkach żywnościowych, widoczny jest stały wzrost ich zbiorów. Nawet mieszkańcy biednych krajów odżywiają się obecnie lepiej niż w XX wieku. Dobrą tego ilustracją są dane zamieszczone $\mathrm{w}$ tab. 2, ukazującej spożycie białka w bogatych i biednych regionach świata. 


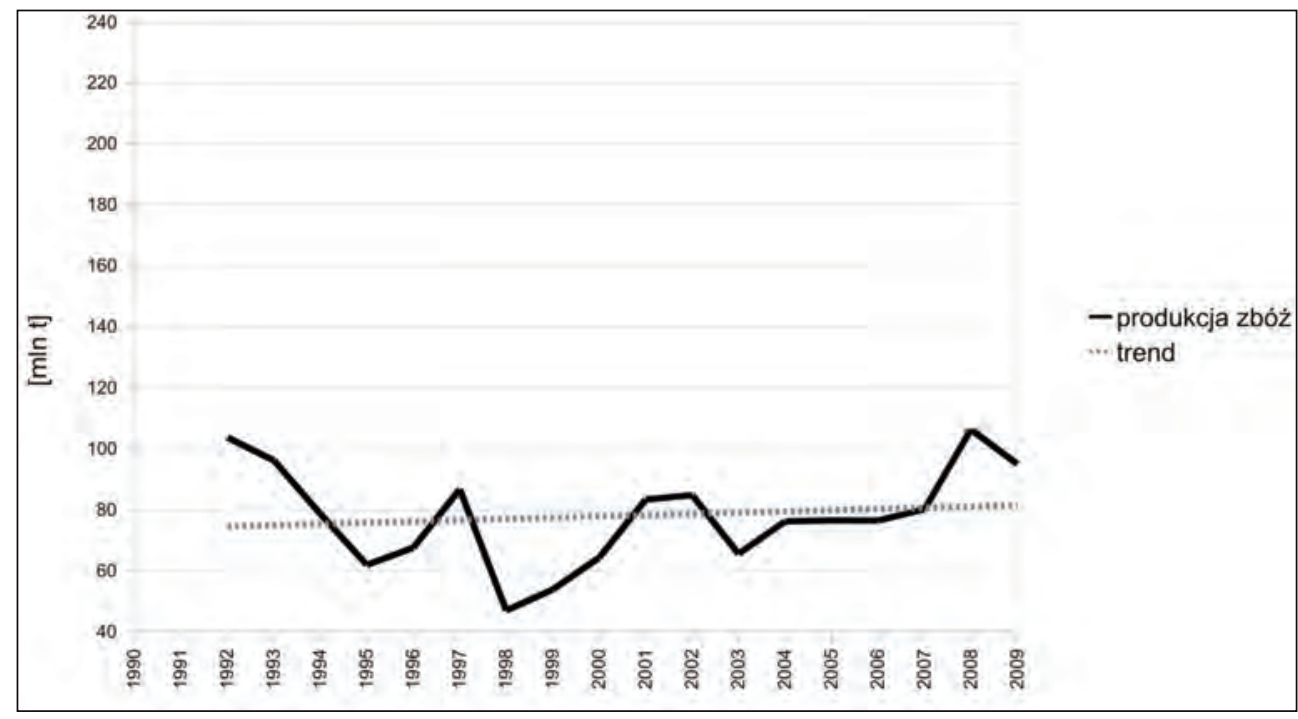

Ryc. 3. Produkcja zbóż w Rosji w latach 1992-2009

Źródło: opracowanie własne na podstawie http://faostat.fao.org 2010

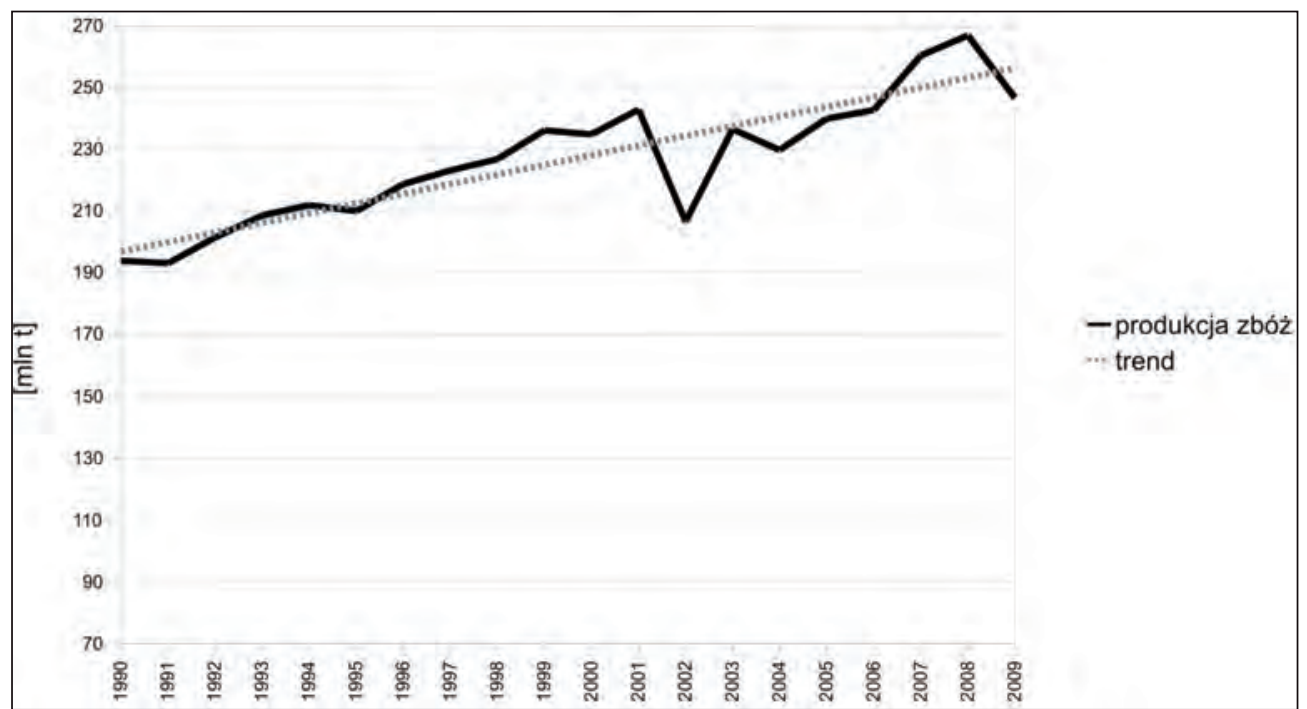

Ryc. 4. Produkcja zbóż w Indiach w latach 1990-2009

Źródło: opracowanie własne na podstawie http://faostat.fao.org 2010 
Tab. 2. Spożycie białka i dynamika zmian zaludnienia w wybranych regionach świata

\begin{tabular}{|c|c|c|c|c|c|c|c|c|c|}
\hline \multirow{2}{*}{$\begin{array}{c}\text { Kraj/region } \\
\text { rok }\end{array}$} & \multirow{2}{*}{$\begin{array}{c}\begin{array}{c}\text { Ludność } \\
{[1961=100]}\end{array} \\
1961-2007\end{array}$} & \multicolumn{4}{|c|}{$\begin{array}{c}\text { Białko } \\
\text { pochodzenia zwierzęcego } \\
\text { [g/os./dzień] }\end{array}$} & \multicolumn{4}{|c|}{$\begin{array}{c}\text { Białko } \\
\text { pochodzenia roślinnego } \\
\text { [g/os./dzień] }\end{array}$} \\
\hline & & 1961 & 1980 & 2000 & 2007 & 1961 & 1980 & 2000 & 2007 \\
\hline Chiny & 202,2 & 3,61 & 7,70 & 29,44 & 33,91 & 36,68 & 47,39 & 56,71 & 54,98 \\
\hline Indie & 254,6 & 6,11 & 6,63 & 9,49 & 10,20 & 46,06 & 42,13 & 45,19 & 47,23 \\
\hline $\begin{array}{l}\text { Stany Zjedn. } \\
\text { Ameryki Płn. }\end{array}$ & 163,1 & 63,02 & 66,54 & 71,74 & 73,09 & 32,24 & 32,05 & 41,61 & 40,52 \\
\hline Europa Zach. & 122,1 & 49,99 & 66,65 & 66,27 & 65,60 & 39,18 & 36,00 & 38,47 & 39,46 \\
\hline
\end{tabular}

Źródło: pracowanie własne na podstawie http://faostat.fao.org 2010

Kraje bogate już w latach 60. ubiegłego wieku osiagnęły satysfakcjonujący poziom spożycia. Do roku 2007 (ryc. 5) wskaźnik ten nie zmienił się istotnie w przypadku białka pochodzenia roślinnego, zauważalny wzrost nastąpił w przypadku białka zwierzęcego. Kraje te jednak przez cały badany okres zwiększały produkcję roślinną, przeznaczając ją zarówno na pasze jak i na eksport. W przypadku Stanów Zjednoczonych, zarówno poziom jak i wzrost spożycia, pozostają na wyższym poziomie niż w innych regionach. Na drugim biegunie znajdują się natomiast Indie i Chiny. Startując z niezwykle niskich poziomów wskaźnika spożycia białka zwierzęcego, osiągnęły dość zróżnicowany postęp. W Indiach spożycie to jest wciąż małe. Może to wynikać m.in. z tradycji i religii. Indie są miejscem narodzin i dominacji trzech znaczących religii, w których spożycie mięsa, przynajmniej niektórych zwierząt, jest zakazane. W hinduizmie dotyczy to wołowiny, w niektórych odmianach buddyzmu w zasadzie wszystkich zwierząt, a w dżinizmie - wręcz wszystkiego, co żyje. Druga pod względem liczby wyznawców religia - islam, także posiada ograniczenia, które dotyczą spożycia wieprzowiny. Z kolei w Chinach przez ostatnie lata znacznie zwiększyło się spożycie białka roślinnego, a w przypadku zwierzęcego wzrost był ponaddziesięciokrotny. Tak dużą dynamikę zmian można było osiągnąć z jednej strony dzięki zwiększającej się stale produkcji, a z drugiej dzięki znacznej redukcji przyrostu naturalnego. W Indiach natomiast podobny wzrost produkcji został „skonsumowany” znaczną dynamiką przyrostu liczby ludności.

Konsekwencje susz czy powodzi w wymienionych czterech krajach mogą mieć daleko idące reperkusje w skali międzynarodowej. Spadek produkcji i niedobory na rynkach światowych powoduje zwykle ograniczenie, a niekiedy nawet całkowity zakaz eksportu, gdy rządy krajowe czy lokalne mają w perspektywie niedobory na rynku lokalnym. Tak stało się choćby w roku $2008 \mathrm{w}$ Indiach, kiedy spodziewano się niedoborów po stratach spowodowanych w 2007 r. przez cyklon w Bangladeszu i słabszych zbiorach w Birmie. Podobnie zachowała się w 2010 r. Rosja wstrzymując sprzedaż ziarna za granicę po wielkich pożarach, które strawiły ok. 1/4 powierzchni upraw zbożowych w tym kraju. W rezultacie takich zachowań dużych producentów (jak i np. powodzi w naszym kraju), w roku bieżącym (2010) dosyć gwałtownie wzrosły ceny zbóż (tab. 3). 


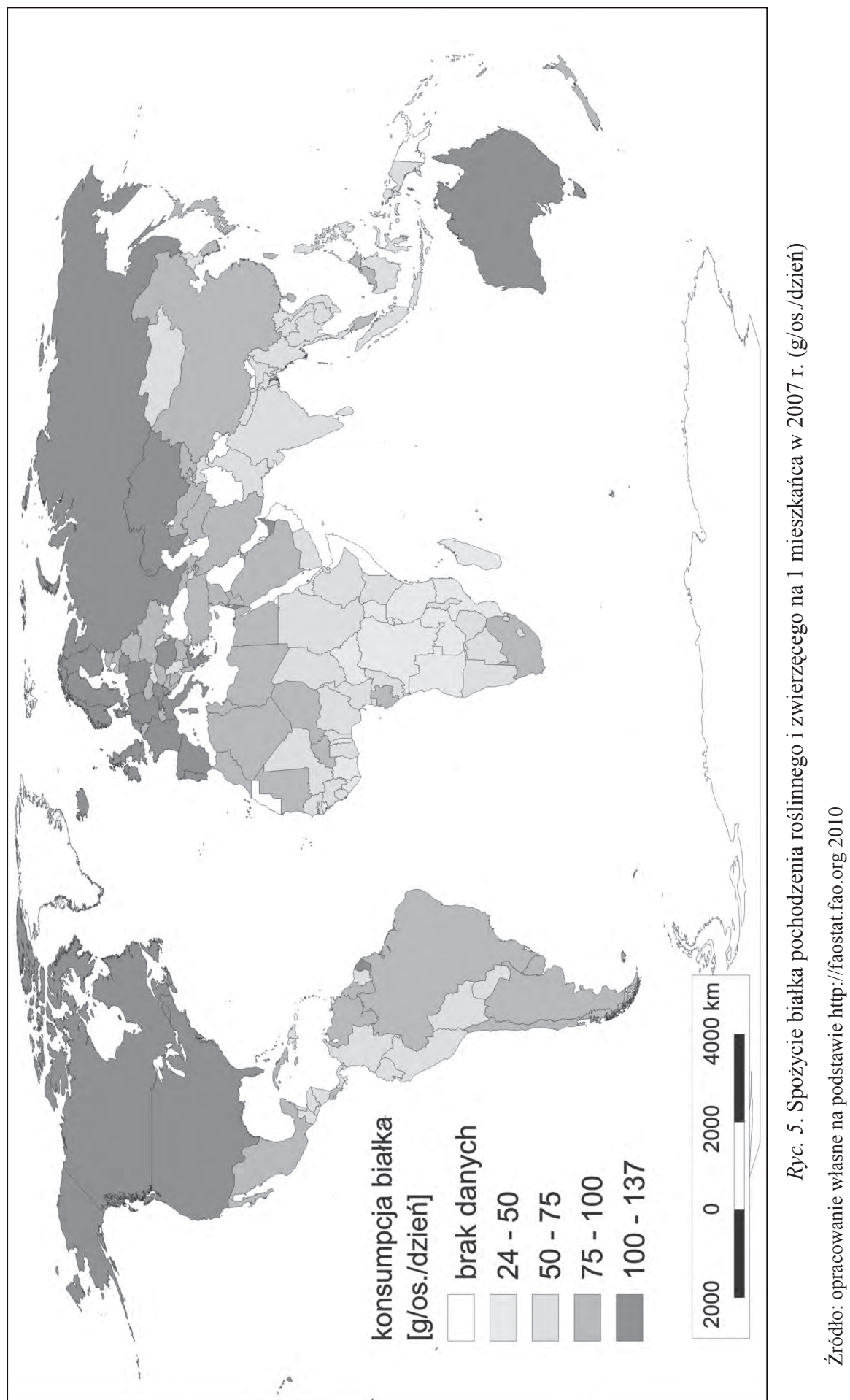


Tab. 3. Zmiany cen skupu pszenicy w Polsce w latach 2009-2010

\begin{tabular}{|c|c|c|c|c|}
\hline okres & I półrocze 2009 & II półrocze 2009 & wrzesień 2010 & październik 2010 \\
\hline cena za 1 dt & 50,55 & 46,22 & 68,83 & 69,09 \\
\hline
\end{tabular}

Źródło: Ceny produktów rolnych w październiku 2010 r., GUS, Warszawa http://www.stat.gov.pl/gus/5840_ 1335 PLK HTML.htm

Zmniejszenie podaży na rynku międzynarodowym może sprzyjać dalszemu ograniczaniu obrotu zbożami również w skali lokalnej. Rolnicy w obawie przed brakiem możliwości zakupu zboża w przyszłości wolą je magazynować, a w konsekwencji następuje spadek ich dochodów przy wzroście cen płaconych przez konsumentów.

Wahania produkcji dotykają w jeszcze większym stopniu kraje małe lub ubogie, choć skala oddziaływania może być często lokalna, ograniczona do jednego państwa. Kraje o mniejszej powierzchni mogą łatwiej podlegać wpływom wynikającym z wahań pogody, a kraje ubogie nie posiadają zazwyczaj rezerw żywnościowych. Przykładów można podawać wiele. Do najbardziej znanych należy susza obejmująca większość Etiopii w latach 80 . XX wieku i wynikająca stąd katastrofalna klęska głodu.

Czy można ograniczyć skalę tych wahań? Otóż jednym z najważniejszych sposobów zapobiegania tym zjawiskom jest zapewnienie odpowiedniej infrastruktury. Zwykle oznacza to budowę i utrzymywanie odpowiednich systemów irygacyjnych. W krajach zamożnych są to zazwyczaj działania prowadzone równocześnie z unowocześnianiem systemów irygacji pod kątem oszczędności i racjonalności wykorzystania wody.

$\mathrm{Na}$ tle tych uwag powstaje pytanie, jak przeciwdziałać zjawiskom kryzysowym, które wiążą się z wahaniami produkcji wywołanymi zjawiskami naturalnymi. Można tu rozważać kilka działań, w wielu wypadkach sprawdzonych w przeszłości:

- powstanie ogólnoświatowej giełdy żywnościowej z regulowanymi cenami;

- upowszechnianie polityki dopłat do produkcji rolnej na wzór UE;

- wprowadzanie ogólnoświatowego monitoringu produkcji, aby z wyprzedzeniem ostrzegać przed grożącymi skutkami i łagodzić lokalne efekty kryzysów;

- wyznaczanie na świecie regionów szczególnie zagrożonych i dla nich wprowadzanie działań infrastrukturalnych;

- opracowywanie, wspieranie inicjatyw wprowadzania technik produkcji żywności w pełni wykorzystujących warunki lokalne bez nadmiernego obciążenia środowiska.

\section{KRYZYS NADPRODUKCJI?}

Jak się okazuje, spore kłopoty na światowych lub regionalnych rynkach żywnościowych wywołać może także nadprodukcja określonych grup roślin lub produktów zwierzęcych. Najbardziej spektakularnym przykładem takich zjawisk jest sytuacja zaistniała w grupie państw związanych z Unią Europejską. Pod koniec lat 70. XX wieku w krajach Europejskiej Wspólnoty Gospodarczej (EWG) zanotowano nadprodukcję żywności na skalę dotąd nieznaną w historii ludzkości. Wcześniej pojawiały się kryzysy związane ze zbyt dużą produkcją pojedynczych produktów, jak miało to miejsce w przypadku np. kawy w pierwszej połowie 
XX wieku. Jednak Wspólna Polityka Rolna (WPR) praktykowana w EWG doprowadziła nie tylko do samowystarczalności Wspólnoty w zakresie zaopatrzenia w większość produktów pochodzących z rolnictwa, ale również do znacznej nadprodukcji. Konsekwencją tego był wyraźny kryzys polityczny, którego efektem była zmiana WPR.

Od początków istnienia EWG założono daleko idące wsparcie dla sektora rolnego. Stabilność raz obranych celów, szeroko zakrojone działania strukturalne oraz szereg narzędzi z zakresu interwencjonizmu i protekcjonizmu państwowego sprzyjały większej wydajności - a co za tym idzie i zwiększaniu produkcji rolniczej. Wśród najważniejszych narzędzi można wymienić skup i sprzedaż interwencyjna, ceny minimalne z działań interwencyjnych oraz cła, a także kwoty ilościowe w imporcie czy dopłaty do eksportu określonych produktów.

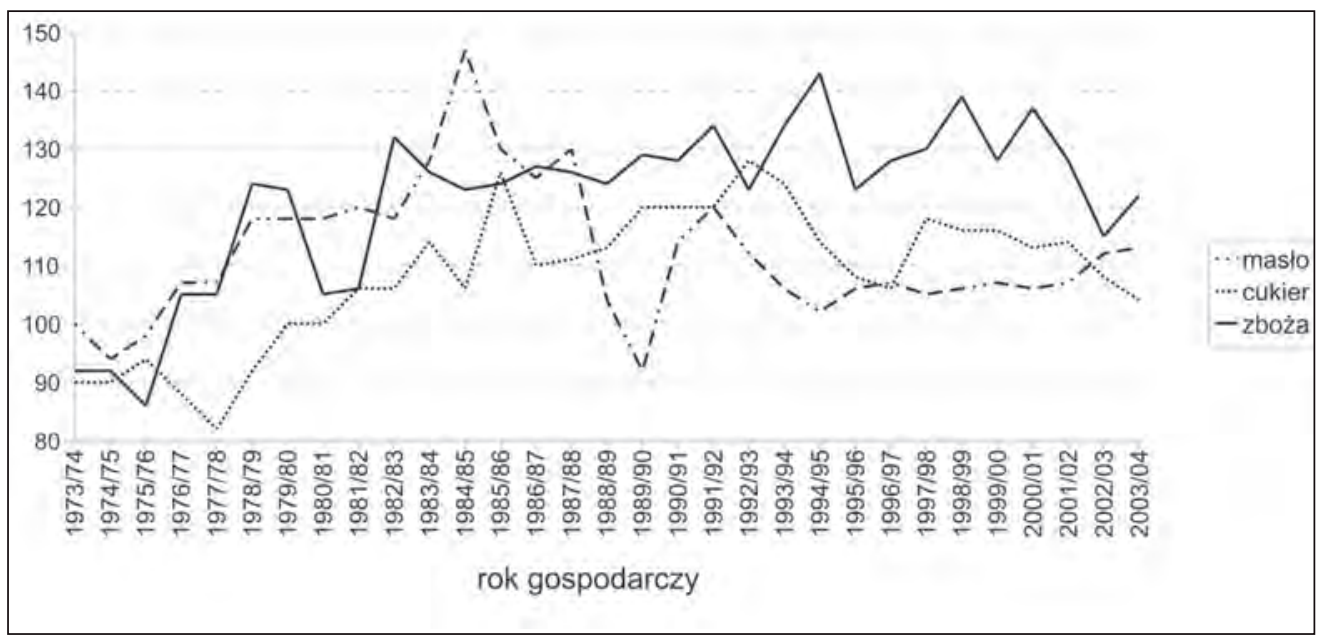

Ryc. 6. Poziom samowystarczalności państw członkowskich UE w latach 1973/74-2003/04 w zakresie masła, cukru i zbóż (100 = poziom samowystarczalności)

Źródło: The Common... 2004

WPR stała się jednak ofiarą własnego sukcesu (Uliszak 1995). W latach 80. XX wieku zaczęło narastać społeczne niezadowolenie z jej efektów. Największe kontrowersje wzbudzała nadprodukcja, ale i coraz większe zagrożenie dla środowiska wynikające m.in. z bardzo wysokiej intensyfikacji kapitałowej rolnictwa. Coraz częściej poddawano w wątpliwość sens rozwijania potencjału produkcyjnego unijnego rolnictwa i ponoszenia kosztów nadprodukcji. A nie były to koszty małe, zważywszy, że w szczytowym okresie magazyny przeznaczone do składowania płodów rolnych na terenie UE musiały pomieścić około 1,3 mln ton masła, 1,1 mln ton wołowiny czy setki milionów ton zbóż (ryc. 6). O ile składowanie zbóż jest dość prostym przedsięwzięciem, o tyle długotrwałe przechowywanie masła czy mięsa pociąga za sobą bardzo wysokie koszty. Z drugiej strony rolnicy wciąż odczuwali, że nie udało się zrealizować jednego z głównych celów polityki rolnej, czyli wyrównania ich dochodów $\mathrm{z}$ dochodami innych grup zawodowych.

Tak więc z sukcesu WPR niezadowoleni byli zarówno producenci, ponieważ nie osiągali spodziewanych dochodów, jak i konsumenci, finansujący unijny budżet przeznaczony w znacznej mierze na realizację kosztownej polityki rolnej. 
Podejmowane pod presją społeczną reformy WPR miały na celu przede wszystkim zmniejszenie nadprodukcji i wielkości dopłat kierowanych do producentów rolnych z unijnego budżetu. Jednak przy tej okazji całe rolnictwo unijne próbowano skierować na nowe tory. Wśród głównych założeń reform wskazywano między innymi:

- zmniejszenie produkcji w przypadku mleka i mięsa wołowego (poprzez kwotowanie);

- zmniejszenie obciążenia dla środowiska (m.in. dzięki zredukowaniu chemizacji rolnictwa i popularyzacji rolnictwa ekologicznego);

- zmniejszenie wielkości dopłat kierowanych do rolników;

- zróżnicowanie źródeł dochodów ludności rolniczej (wielofunkcyjność terenów wiejskich).

Wspólna Polityka Rolna podlega dalszym przemianom, co obecnie wynika również z różnic pomiędzy wsparciem dla rolników ze „starej” Unii i nowych państw członkowskich. Jednak problem, który zapoczątkował szeroką debatę nad reformą WPR - czyli nadprodukcja - wydaje się być już rozwiązany.

\section{ROLNICTWO W OKRESIE ŚWIATOWEGO KRYZYSU EKONOMICZNEGO}

Trudno dać jednoznaczną odpowiedź na pytanie, czy światowy kryzys ekonomiczny w sposób oczywisty wywołuje trudności w rolnictwie, które również można określić mianem kryzysu. Trudno na przykład stwierdzić, że przy ogólnym spadku PKB, obserwowanym np. w prawie całej Europie, Stanach Zjednoczonych czy Japonii, rolnictwo tych krajów również znajduje się w stanie kryzysu (Shane i in. 2009). Niezależnie bowiem od sytuacji budżetowej tych krajów, otrzymuje ono duże wsparcie w ramach np. wspomnianej wcześniej unijnej polityki rolnej (WPR). Z pewnością można stwierdzić, że malejące dochody ludności krajów Wspólnoty czy innych krajów osłabiają popyt na towary luksusowe, do których można zaliczyć wino i luksusowe wyroby czekoladowe. Może to wpływać na spadek popytu na określone surowce pochodzenia rolniczego i z tego tytułu np. rolnicy uprawiający winną latorośl mogą osiagać niższe dochody.

Światowy kryzys w niewielkim stopniu zakłóca działalność rolnictwa i ogranicza jego rozwój w UE, Stanach Zjednoczonych czy innych bogatych obszarach. Można natomiast mówić o wielu przejawach kryzysu strukturalnego w rolnictwie krajów europejskich, a przede wszystkim kryzysu ekologicznego.

Kryzys strukturalny przejawia się w niedostosowaniu (głównie struktury obszarowej) do współczesnych reguł ekonomicznych. Tylko bowiem odpowiedniej wielkości gospodarstwo gwarantuje racjonalne wykorzystanie maszyn i narzędzi rolniczych. Są nim dotknięte głównie nowe kraje UE (np. Polska, Węgry, Rumunia), które przechodzą intensywny proces zmian mających poprawić przede wszystkim strukturę obszarową gospodarstw rolnych. Sytuacja kryzysowa rolnictwa tych krajów widoczna jest przede wszystkim w utajonym bezrobociu, niskiej efektywności zatrudnionych i posiadanego sprzętu rolniczego. Trudno jednak oczekiwać szybkiego wyjścia z tej trudnej sytuacji, ponieważ warunkiem podstawowym jest przemieszczenie znacznej ilości siły roboczej rolnictwa do innych działów, a to jest możliwe dopiero przy dużej aktywności pozarolniczych sfer gospodarki. Oczekuje się w związku z tym przede wszystkim rozwoju usług pozarolniczych jak i związanych z rolnictwem, w których znajdzie zatrudnienie również ludność rolnicza. Taki proces przeszło rolnictwo 
Europy Zachodniej, którego sytuację w zakresie liczby gospodarstw rolnych przedstawiono w tab. 4.

Tab. 4. Liczba gospodarstw rolnych w wybranych krajach Unii Europejskiej w latach 1960-2007

\begin{tabular}{|l|r|r|r|r|r|r|}
\hline \multicolumn{1}{|c|}{ kraj } & $1966 / 67$ & 1975 & 1980 & $1989 / 90$ & 2000 & \multicolumn{1}{c|}{2007} \\
\hline Belgia & 214,8 & 138,1 & 115,1 & 85,0 & 61,7 & 48,0 \\
\hline Dania & & 132,3 & 122,7 & 81,3 & 57,8 & 44,6 \\
\hline RFN $^{1}$ & 1246,0 & 907,9 & 849,9 & 653,6 & 472,0 & 370,5 \\
\hline Francja & 1708,0 & 1315,1 & 1255,3 & 923,6 & & 527,4 \\
\hline Portugalia & & & & 598,7 & 416,0 & 275,1 \\
\hline
\end{tabular}

Źródło: opracowanie własne na podstawie: Farm structure, historical results - surveys from 1966/67 to 1997, 2000, Eurostat oraz Eurostat 2010 (od 1989/90 dane łącznie z byłą NRD)

Na podstawie przedstawionych danych (tab. 4) można stwierdzić, że w krajach tej części Europy usunięto już dość wcześnie podstawowe przyczyny kryzysu strukturalnego. Jednak wielkim problemem rolnictwa związanym z jego rozwojem jest silne zniszczenie środowiska przyrodniczego w wyniku intensyfikacji produkcji. Mówi się więc w tym kontekście o kryzysie ekologicznym rolnictwa. Dlatego też Unia, przeciwdziałając temu zjawisku, proponuje m.in. w ramach WPR powstanie tzw. rolnictwa ekologicznego. Jest ono alternatywa dla rolnictwa uprzemysłowionego bogatych krajów, a także propozycją dla nowych członków Unii, którzy mogą w gospodarstwach ekologicznych zagospodarować posiadane rezerwy siły roboczej. Ta idea ekologicznej żywności jest przenoszona też na kraje biedne oraz ich dawne kolonie. Popyt i moda na ekologiczną żywność stymuluje produkcję nawet takich produktów jak kakao, kawa czy herbata ekologiczna.

Pomimo relatywnie mniejszego wpływu kryzysu ekonomicznego na rolnictwo w porównaniu z sektorem finansowym, wskazuje się jednak na szereg negatywnych efektów. Jako podstawowe skutki kryzysu dla rolnictwa w skali świata można wskazać:

- zmniejszenie dochodów emigrantów żyjących w bogatych krajach objętych kryzysem, a w konsekwencji zmniejszenie przepływu pieniędzy do krajów rodzinnych (głównie do rodzin wciąż żyjących na wsi);

- powroty emigrantów pozbawionych pracy do rodzinnych gospodarstw rolnych i zwiększanie tym samym bezrobocia na wsi;

- zmniejszenie dochodów rolników w wyniku zmniejszonego popytu na niektóre produkty pochodzące z rolnictwa (np. kwiaty cięte, bawełna);

- trudniejszy dostęp do kredytowania działalności rolniczej w obliczu niepewnej sytuacji niektórych banków i zaostrzania polityki kredytowej.

\section{KRYZYS O PODEOŻU POLITYCZNYM}

Wiele sytuacji kryzysowych we współczesnym rolnictwie wynika z przyczyn politycznych i ideologicznych.

Tragiczna sytuacja żywnościowa Korei Północnej ma niewątpliwy związek z kryzysem tamtejszego rolnictwa, które z przyczyn ideologicznych funkcjonuje jako rolnictwo kolek- 
tywne, pozbawione tych czynników motywujących człowieka do pracy, które daje indywidualne posiadanie ziemi i innych środków produkcji. Innym przykładem występującego kryzysu w rolnictwie jest Ukraina. Kraj ten nie podjął dotąd konsekwentnie realizowanych reform przekształcających dawne kolektywne struktury rolnicze w gospodarstwa prywatne. Jego wielkim problem są ogromne wahania produkcji, postępująca depopulacja na terenach rolniczych, wygasający przyrost naturalny i starzenie się ludności rolniczej. W konsekwencji zbiory zbóż w tym kraju w roku maksymalnej wydajności (2008) wyniosły $58 \mathrm{mln}$ t, natomiast w depresyjnym (2003) było to tylko niecałe $20 \mathrm{mln}$ t (2,5 razy mniej). Wskutek tych wahań kraj ten nie jest w stanie ustabilizować na przykład chowu zwierząt na określonym poziomie, jaki jest charakterystyczny dla normalnego rolnictwa.

Przykładem wpływu decyzji politycznych na kryzys rolnictwa może być Laos (gdzie dalej forsuje się kolektywne formy gospodarowania). Tylko w ciagu ostatnich lat udział lasów zmniejszył się z ponad 75\% w roku 1990 do niespełna 69\% w roku 2008 (Faostat 2010). W tym górzystym kraju trzebi się lasy na stokach o dużym nachyleniu i próbuje się nasadzać bananowce oraz uprawiać różne rośliny bulwiaste. Odsłonięta cienka warstwa gleby górskiej jest szybko zmywana przez ulewne deszcze. W rezultacie po paru latach dochodzi do całkowitej degradacji terenu. Mimo widocznych niepowodzeń takich działań, są one prowadzone nadal, gdyż ich przesłanki wynikają nie z przyczyn ekonomicznych, lecz ideologicznych. Ocenia się (Socio-economic Atlas... 2008), że aż około 42\% powierzchni lądowej Laosu pokryte jest rachitycznymi zaroślami leśnymi będącymi pozostałościami po takim sposobie gospodarowania.

Innym, szeroko dyskutowanym ostatnio przykładem wpływu decyzji politycznych na kryzys w rolnictwie jest Zimbabwe. Według informacji rządu tego kraju, przed rokiem 2002 biali farmerzy (w liczbie około 4400 osób) władali jedną trzecią użytków rolnych tej dawnej brytyjskiej kolonii. W tym czasie ponad milion miejscowych chłopów musiało się zadowolić 38\% całkowitej powierzchni użytków. Farmerzy pochodzenia brytyjskiego mieli swoje gospodarstwa na najżyźniejszych terenach, chłopi gospodarowali zazwyczaj na terenach o bardzo słabej glebie. Była to pozostałość systemu kolonialnego i od obalenia rządów białej mniejszości w 1980 r. i proklamowania Zimbabwe niewiele się pod tym względem zmieniło. Ogłoszony w lipcu 2000 r. program reformy agrarnej zakładał przejęcie towarowych gospodarstw należących do białych i rozdzielenie ich pomiędzy chłopów. Produkcja rolna Zimbabwe załamała się, podobnie jak cała krajowa gospodarka. ONZ sklasyfikował obecnie ten kraj na samym końcu rankingu HDI (Human Development Index). Od roku 2000, kiedy wskaźnik HDI dla Zimbabwe wynosił 0,23, zmniejszył się on obecnie do 0,14 .

Również nasze rolnictwo padło w ostatnich latach ofiarą politycznych nieporozumień z Rosją. Dla nikogo nie jest tajemnica, że wprowadzenie zakazu importu polskiego mięsa do Rosji w 2005 r. było pochodną znacznego pogorszenia stosunków między Polską i Rosją. Eksport do Rosji, z którą nasz kraj ma ujemny bilans handlowy, jest dla polskiej gospodarki bardzo ważny. Ale ograniczenie eksportu polskiego mięsa okazało się jeszcze ważniejsze dla rolników. W momencie zamknięcia rynku rosyjskiego i błyskawicznego ograniczenia przerobu w polskich zakładach mięsnych, to polscy rolnicy pozostali ze zwierzętami, których nikt nie chciał od nich kupić. Podobne działania zostały podjęte przez Rosjan również w stosunku do sztandarowych produktów spożywczych innych krajów toczących różnorodne spory, a nawet pozostających z władzami w Moskwie w konflikcie. Tak stało się z gruzińską wodą mineralną czy mołdawskim winem. 


\section{CZY POLSKIE ROLNICTWO ZNAJDUJE SIE W KRYZYSIE?}

Z szacunków za rok 2010 wynika, że dochody polskich rolników wynoszą nieco ponad $60 \%$ poziomu dochodów innych grup zawodowych. Dzieje się tak mimo niewątpliwie sporego wsparcia, jakie nasi rolnicy otrzymują z budżetu Unii Europejskiej. Zostało ono jednak ustalone na niższym poziomie w stosunku do krajów „starej” Unii podczas negocjacji akcesyjnych przed 2004 r. Z danych, jakie podają polskie źródła, wynika, że od roku 2005 dochody rolników wzrosły w naszym kraju o około $50 \%$. W całej Unii w tym czasie szybciej rosły tylko dochody rolników bułgarskich (EU27 real agricultural...). Z wypowiedzi polskich rolników i działaczy związkowych wynika, że nasze rolnictwo w większości ogarnięte jest kryzysem ekonomicznym. W omawianiu sytuacji kryzysowej naszego rolnictwa trzeba uwzględnić jego duże spolaryzowanie strukturalne i dochodowe oraz zwrócić uwagę na wahania koniunkturalne w podaży i popycie na określone grupy produktów rolnych. Z pewnością znaczna część polskiego rolnictwa obejmująca duże pod względem powierzchni gospodarstwa o wyspecjalizowanej produkcji osiaga wysokie dochody, które satysfakcjonują prowadzących je rolników i ich rodziny. Ich sytuacja także w sferze techniczno-produkcyjnej jest korzystna i w wielu przypadkach porównywalna z gospodarstwami z Europy Zachodniej.

W odmiennej sytuacji natomiast znajduje się część polskiego rolnictwa, którą tworzą drobne gospodarstwa. Dysponują one dużymi zasobami siły roboczej, ale mają mało ziemi i niewielką produkcję, którą przeznaczają głównie na własne potrzeby. Jeśli nie znajdują się blisko miejskiego rynku zbytu lub nie produkują żywności ekologicznej - to są właściwie bez perspektyw. Ich kryzysowa sytuacja wynika z bardzo niskich dochodów i braku możliwości inwestowania. Ich ziemia jest niezbyt intensywnie czy racjonalnie wykorzystywana. Przeszkodą w dążeniu do bardziej racjonalnego gospodarowania jest też niechęć do różnych form zespołowego gospodarowania polegającego na łączeniu ziemi w większe obszary celem zespołowej gospodarki. Jest to również bolączką większych producentów rolnych. Często występują oni samotnie w kontaktach biznesowych z pośrednikami czy przetwórcami i nie są w stanie uzyskać zwiększenia swoich dochodów. Różnicę pomiędzy ceną płaconą producentom a oferowaną konsumentom przechwytują właśnie przetwórcy, handlowcy (detaliczni i hurtowi) czy pośrednicy. Sprawdzone mechanizmy spółdzielczych organizacji przetwórczych i sieci handlowych, dobrze funkcjonujące np. w Szwajcarii czy Danii, na razie nie mają szans na zastosowanie w naszym kraju.

Inny kompleks spraw tworzących okresowe kryzysy w samym rolnictwie dotyczy dużej zmienności cen na określone produkty pochodzące z rolnictwa. Niestabilność ta jest pochodną wahań koniunkturalnych na rynkach światowych, z którymi w wielu dziedzinach nasze rolnictwo ma silne związki. Dotyczy to w szczególności tych produktów, które rolnicy wytwarzają w dużych ilościach i są znaczącymi producentami w Europie, a nawet w świecie - mięsa drobiowego, mleka, jabłek, rzepaku, cukru, mięsa wieprzowego.

\section{Podsumowanie}

Rolnictwo działa cały czas pod presją rosnącej liczby ludności oraz rosnących potrzeb (szczególnie w przypadku społeczeństw o powiększających się dochodach). Jest to przy- 
czyną ciągłego dążenia do wzrostu produkcji i powiększającego się zagrożenia ekologicznego. Pozostając pod przemożnym wpływem warunków przyrodniczych produkcja globalna rolnictwa ulega ciagłym wahaniom ze względu na zróżnicowane warunki pogodowe w poszczególnych latach czy dłuższych okresach. Wyzwaniem pozostaje przede wszystkim zapewnienie odpowiedniej ilości wody. Kryzysy ekonomiczne, takie jak obecny, mają wpływ przede wszystkim na sytuację najuboższych grup społecznych zarówno w miastach jak i na wsi (bezrolni), pogłębiając zjawiska już istniejące z innych przyczyn (niedożywienie w znacznej części świata czy głód w niektórych regionach). Coraz większa wzajemna zależność gospodarek krajów wysokorozwiniętych i uboższych może skłaniać do stwierdzenia, że częściej niż w przeszłości kryzysy ekonomiczne bogatych będą wpływać również na biednych.

Liczba głodnych i niedożywionych ludzi na świecie przekroczyła w roku 2009 1 miliard i jest rekordowa od lat 70. XX wieku. Nie jest to jednak wynik wyłącznie ostatniego kryzysu ekonomicznego, ale splotu wielu przyrodniczych, ekologicznych, politycznych i ekonomicznych elementów (kryzysów) składających się na trudną sytuację rolnictwa w ostatnich latach.

\section{Literatura}

EU27 real agricultural income per worker up by 12,3\%, Eurostat Newsrelease 201/2010 - 20 December 2010.

Shane M., Liefert W., Morehart M., Peters M., Dillard J., Torgerson D., Edmondson W., 2009, The 2008/2009 World Economic Crisis What It Means for U.S. Agriculture, United States Department of Agriculture.

Socio-economic Atlas of Lao PDR, 2008, Swiss National Centre of Competence in Research (NCCR) North-South and Geographica Bernensia, Bern, Switzerland.

The Common Agricultural Policy Explained, European Communities 2004.

The State of Food Insecurity in the World 2009. Economic crises - impacts and lessons learned, 2009, FAO, Rome.

The State of Food Insecurity in the World 2010. Addressing food security in protracted crises, 2010, FAO, Rome.

Uliszak R., 1995, Główne problemy produkcyjne i ekologiczne rolnictwa Unii Europejskiej, Geografia w Szkole, nr 3, s. 131-138.

\section{Manifestations of crisis in contemporary agriculture}

The crisis in agriculture seems to be different than in other economic sectors. This is the result of agriculture's specificity. There is a very strong relationship between farmers and the results of their work with natural environment. These connections are much more important than in industry or services. Food production is of greatest importance. People have to eat even during very strong economic crisis. Still, there are some types of crises present in contemporary agriculture. Some of them resemble the crises present in the last thousands of years, but some of them are characteristic for current situation.

In the article the following types of contemporary agricultural problems were discussed: the crisis caused by natural environment conditions (the case of Russia and India), overproduction (the case 
of CAP in EU), the economic crisis (the case of West), the crisis caused by political tensions (the case of Laos and Zimbabwe) as well as the situation of Polish agriculture (after Poland's accession to EU).

dr Radosław Uliszak

Uniwersytet Pedagogiczny w Krakowie

Instytut Geografii

Zakład Geografii Społeczno-Ekonomicznej

e-mail: ulira@up.krakow.pl 